(36) Frankl-Hochwart L. von. und Fröhlich, A.- “ Zur Kenntniss der Wirkung des Hypophysins (Pituitrins, Parke Davis \& Co.) auf das sympathische und autonome Nervensystem." Arch. f. Exper. Path. u. Pharm., 1910, Vol. LXIII, p. 347.

(37) Kepinow, D. - "Ueber den Synergismus von Hypophysisextrakt und Adrenalin." Arch.f. Exper. Path. u. Pharm., 1912, Vol. LXVII, pp. 260-4.

(38) Gottlieb, reference Meltzer.-(Bibliography 39).

(39) Meltzer, S. J. - "The influence of the infundibular portion of the hypophysis upon the pupil." Proc. Soc. Exper. Biol. and Med., 1911-12, Vol. IX, p. 103.

(40) Fröhlich, A., und Pick, E. P.-“Zur Kenntniss der Wirkungen der Hypophysenpräparate, III. Mitteilg. Beeinflussung der Ergotoxinwirkung durch Hypophysin." Arch.f. Exper. Path. u. Pharm., 1913, Vol. LXXIV, p. 114.

(41) Dale, H. H.-Loc. cit., pp. $438,440$.

(42) Githens, T. S.- "The influence of ergotoxin on the pupil of the rabbit." Proc. Soc. Exper. Biol. and Med., 1917, Vol. XIV, 44, p. 70.

(43) Githens, T. S. and Meltzer, S. J. - Influence of pituitrin and of adrenalin on the pupil of normal and ganglionectomized rabbits." Proc. Soc. Exper. Biol. and Med., 1916, Vol. XIV, 33, p. 53.

(44) Langley, J. N.- " Observations on the physiological action of extracts of the supra-renal bodies." Jl. of Physiol., 1901, Vol. XXVII, p. 237.

(45) Brodie, T. G., and Dixon, W. E.-Loc. cit., p. 493.

(46) Elliott, T. R.-Loc, cit., pp. 417, 418.

(47) Bayer, G. and Peter L.- "Zur Kenntniss des Neurochemismus der Hypophyse." Arch.f. Exper. Path. u. Pharm., 1911, Vol. LXIV, p. 204.

(48) Joseph, D. R. - "The effect of adrenalin on the pupil after removal of the ciliary ganglion." Proc. Soc. Exper. Biol. and Med., 1915. Vol. XII, p. 138.

(49) Joseph, D. R.-." The inhibitory effect of adrenalin upon the sphincter pupillae." Proc. Soc. Exper. Biol. and Med., 1915, Vol. XII, p. 212.

(50) Anderson, H. K.-Loc. cit., p. 417.

\title{
A METHOD OF IRIDOTOMY
}

BY

\author{
M. S. MAYOU, \\ LONDON.
}

THE following method of performing iridotomy has been practised by the author for the last fifteen years. Taken as a whole he has found it more successful than any other method which he has tried, as it yields a much larger opening, and is therefore less liable to be closed by subsequent inflammatory exudation. He makes no claim of originality for the operation; indeed, he has seen the operation performed by other ophthalmic surgeons, but does not know who first performed it.* The method does not seem to be generally known.

The operation is usually performed under a general anaesthetic, but this is not essential.

First step. The surgeon stands facing the patient on the same

* Since writing the above, I find in the Report of the Ophthalmic Department of King's College Hospital, Vol. VII., 1900, a case recorded in which the operation was done by Mr. MacHardy.-M.S.M. 
side as the eye to be operated on. A long, narrow, bent broad cutting needle is passed into the anterior chamber from the limbus downwards and inwards, and is driven directly through the iris and underlying capsule. The needle is then made to pass in an upward and outward direction behind the iris into the pupillary area above, or if no pupil be present, again through the iris (Fig. 1.) The bent broad needle is made to cut laterally by slightly deflecting the handle so as to produce a band of iris and capsule; the cutting needle is then withdrawn. Care should be taken as far as possible to prevent the loss of aqueous.

Second step. A Tyrrell's hook, bent to the correct angle, is

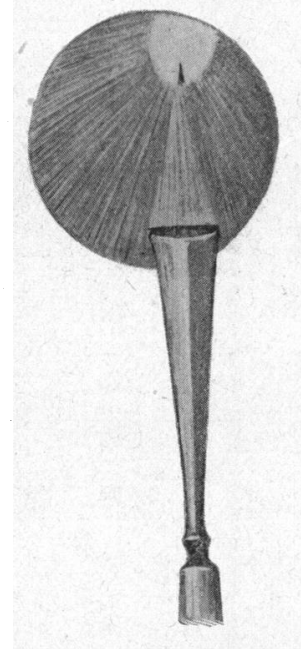

FIG. 1.

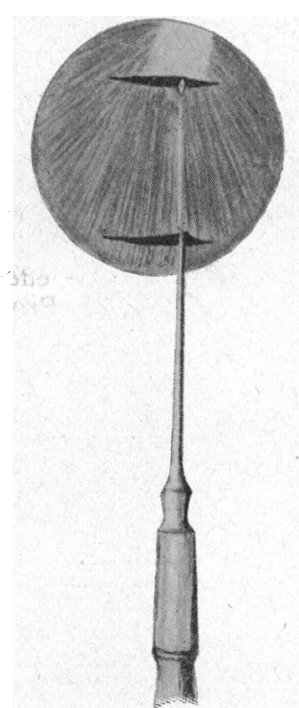

FIG. 2.

passed beneath the band (Fig. 2), which is drawn into the wound and removed with iris scissors. A large opening is thus obtained with a minimum amount of trauma. If the hook should slip, the band may be seized with iris forceps, withdrawn from the wound, and removed.

The operation has the advantage that if it fails from blocking of the opening by inflammatory tissue, a tight fibrous band is formed between the old wound above and the new wound below, and this can subsequently be divided with a pair of fine iris scissors through a lateral incision at the limbus; the tension of the band will cause it to spring apart when divided. 